\title{
СЕСТРИНСЬКІ ТЕХНОЛОГІЇ НА ЕТАПІ СТАЦІОНАРНОГО ЛІКУВАННЯ ХВОРИХ, ЯКІ ПОТРЕБУЮТЬ ЕНДОПРОТЕЗУВАННЯ КУЛЬШОВОГО СУГЛОБА
}

\author{
І. В. Костючок ${ }^{1}$, Н. Ю. Лучишин ${ }^{2}$ \\ ${ }^{1}$ Київська міська клінічна лікарня № 7 \\ ${ }^{2} Д в Н 3$ «Тернопільський державний медичний університет \\ імені І. Я. Горбачевського МОЗ Украӥни»
}

\begin{abstract}
У статті подано основні функції медичної сестри у забезпеченні лікувального процесу та організації догляду за пацієнтами з патологією кульшових суглобів, які перебувають на стаціонарному лікуванні в ортопедичному відділенні. Обгрунтовано необхідність якісного супроводу пацієнтів 3 ендопротезами грамотними медичними сестрами, що дозволяє досягти успішного і біомеханічно коректного відновлення пацієнтів.
\end{abstract}

\section{NURSING TECHNOLOGIES OF THE INPATIENT STAGE OF TREATMENT OF PATIENTS UNDERGOING HIP REPLACEMENT}

\author{
I. V. Kostyuchok ${ }^{1}$, N. Yu. Luchyshyn ${ }^{2}$ \\ ${ }^{1}$ Kyiv City Clinical Hospital No. 7 \\ ${ }^{2}$ I. Horbachevsky Ternopil State Medical University
}

\begin{abstract}
The article presents the main duties of a nurse in providing treatment and care for patients with hip joints pathology undergoing inpatient treatment in the orthopedic department. The article substantiates the necessity of skilled nursing services for patients who undergo hip replacement surgery that allows achieving successful and biomechanically correct restoration of hip anatomy.
\end{abstract}

Вступ. Лікувальний процес будь-якого захворювання складається з лікарського та сестринського. Хвороби опорно-рухового апарату не $\epsilon$ винятком. Вони приносять психоемоційні та фізичні страждання, обмежують фізичну активність і здатність до пересування, погіршують якість життя, нерідко призводять до інвалідизації хворих. Тому роль медсестри в досягненні позитивного результату їх лікування вагоме і має свої особливості.

Сьогодення висуває перед медичними сестрами ряд вимог, однією з яких $є$ відповідна обізнаність у питаннях діяльності, якій присвячена їхня професійна робота.

Основна частина. Згідно з даними Всесвітньої організації охорони здоров'я, в загальній структурі суглобової патології коксартрози стабільно займають друге місце після гонартрозів і перше - за термінами тимчасової й стійкої непрацездатності [1, 4]. Довготривале захворювання на коксартроз призводить до розвитку больових відчуттів у кульшовому суглобі, (ㄱ. І. В. Костючок, Н. Ю. Лучишин, 2019 зменшення сили м'язів хворої кінцівки, контрактур та обмеження в пересуванні (С. М. Бубновський, 2010). Тому використання ефективних методів лікування, в тому числі хірургічних (тотального ендопротезування), є надзвичайно важливим для підтримання якості життя пацієнтів [3].

Важливим і до кінця невирішеним питанням в ендопротезуванні $\epsilon$ проблема реабілітації хворих $з$ ендопротезами суглобів. Ендопротезування позбавляє больового синдрому, зменшує кульгавість або повністю відновлює ходу і дає можливість відновити соціальний статус пацієнта. Операція тотального ендопротезування здатна відновити нормальні рухи в кульшовому суглобі, однак, тільки після інтенсивної фізичної реабілітації пацієнт зможе відновити повну силу. Все це визначає необхідність якісного супроводу пацієнтів з ендопротезами грамотними медичними сестрами, що $є$ пріоритетним та дозволяє досягти успішного і біомеханічно коректного відновлення пацієнтів та, певною мірою, вплинути на якість їх життя $[1,9]$. 
Для досягнення високої якості наданої медичної допомоги необхідно правильно організувати виконання всіх основних функцій медичної сестри, що гарантуватиме пацієнтові впевненість в отриманні більш якісної та кваліфікованої медичної допомоги, прискорить процес адаптації в умовах стаціонару, покращить догляд, у тому числі в питаннях особистої гігієни. Медична технологія - це якраз такий алгоритм дій медичного персоналу, регламентований за часом, що забезпечує узгодженість дій реабілітаційної команди $[1,11]$.

Якість сестринської допомоги, окрім ставлення медичної сестри до своєї справи і від її особистих якостей, безпосередньо залежить від знань і умінь кожної медичної сестри, від того, які вимоги висувають до медичної сестри і які функції на неї покладені.

Аналіз вітчизняної та закордонної літератури дозволив сформулювати послідовність медичної технології при здійсненні догляду за пацієнтами, які потребують ендопротезування кульшового суглоба та в період післяопераційного реабілітаційного процесу, що перебуває в межах компетенції медичної сестри [8-10].

У передопераційний період, метою якого є повноцінна підготовка хворого до проведення ендопротезування кульшових суглобів, поліпшення психоемоційного стану хворого і набуття впевненості в одужанні [2], медичній сестрі необхідно:

- оцінити розуміння пацієнта про планове операційне втручання, за необхідності надати додаткові роз'яснення. Розуміння ситуації зменшує занепокоєння і підвищує рівень комплаєнсу пацієнта в процесі післяопераційної реабілітації;

- отримати інформацію для оцінки фізичного стану пацієнта, в тому числі діапазон руху уражених суглобів. Ця інформація не тільки дозволяє медсестрі забезпечувати індивідуальний підхід у догляді за конкретним пацієнтом, але й слугує базою для порівняння з даними в післяопераційний період [5];

- пояснити необхідні обмеження в післяопераційний період;

- навчити пацієнта користуватися засобами для зміни положення в ліжку. Пацієнт, який оволодів техніками переміщення до операції, зможе більш ефективно використовувати їх в післяопераційний період;

- навчити правильно виконувати вправи у період реабілітації після перенесеної операції на суглобі. Це сприятиме зміцненню м'язів для стабільності суглобів, буде запобігати атрофії м'язів, розвитку суглобових контрактур і венозного стазу та можливої тромбоемболії;
- навчити пацієнта виконувати дихальну гімнастику (з використанням кашлю і глибокого дихання). Правильне дихання особливо важливе для пацієнтів, яким показане тотальне ендопротезування для запобігання респіраторним ускладненням, пов'язаним із нерухомістю, ефектами загального знеболювання та зниженням мукоциліарного кліренсу в літніх пацієнтів [6];

- обговорити післяопераційні засоби контролю болю, включно застосування аналгезії, контрольованої пацієнтом (АКП). Важливо, щоб пацієнт зрозумів мету застосування післяопераційних заходів боротьби з больовим синдромом для покращення рухливості та зменшення ускладнень, пов'язаних із нерухомістю;

- навчити здійснювати або провести передопераційну гігієнічну підготовку, що сприятиме зменшенню інфікування операційної рани транзитними мікроорганізмами;

- ввести призначені у передопераційний період антибіотики для подальшого зниження ризику інфекції.

У ранній післяопераційний період (1-7 днів після операції), метою якого $є$ профілактика післяопераційних ускладнень, зняття операційного стресу, профілактика контрактури в оперованому суглобі, активізація в ліжку, підготовка до вставання, сестринські медичні технології полягають у:

- контролі життєвих показників, включно температуру та рівень свідомості, кожні 4 год або частіше. Про значні зміни медична сестра повинна повідомити лікаря. Ці звичайні показники надають інформацію про стан серцево-судинної системи пацієнта і слугують ранніми ознаками таких ускладнень, як кровотеча, дегідратації, приєднання інфекції;

- здійсненні оцінки периферійної нервової системи на ураженій кінцівці (колір шкіри, температура, пульс і наповнення капілярів, рухливість і чутливість) щогодини протягом перших 12-24 год, потім - кожні 2-4 год. Про патологічні результати потрібно негайно повідомити лікаря. У результаті операції можливе порушення кровопостачання або іннервації ураженої кінцівки, тому вчасне виявлення відхилень $\epsilon$ важливим для збереження функції кінцівки;

- контролі післяопераційної крововтрати шляхом підрахунку виділень з дренажних трубок через кожні 4 год і оцінки пов'язки. Значна втрата крові може відбуватися при тотальному ендопротезуванні;

- зміцненні пов'язки за необхідності. Пов'язку зазвичай змінюють через 24-48 год після операції, частіше - при надмірній кровотечі; 
- підтримці внутрішньовенних інфузій та точної реєстрації введеної та виведеної рідин, оскільки через втрати крові та рідини під час операції, а також ефекти анестетика пацієнт має ризик розвитку дегідратації;

- підтримці ліжкового режиму та відповідного положення ураженої кінцівки з використанням шин, фіксаторів або інших засобів. Правильне розташування ураженої кінцівки життєво важливо в початковий післяопераційний період із метою попередження дислокації протеза;

• допомозі пацієнту змінювати положення тіла в ліжку принаймні кожні 2 год, оскільки зміна положення допомагає запобігти виникненню пролежнів й інших ускладнень через знерухомлення;

- нагадуванні пацієнту кожні 2 год використовувати дихальну гімнастику, необхідну для запобігання таких респіраторних ускладнень, як пневмонія;

- оцінці рівня комфорту пацієнта. Підтримувати АКП або іншої призначеної аналгезії для підтримки комфорту. Адекватне лікування болю сприяє загоєнню і мобільності;

- допомозі пацієнту встати з ліжка, щойно це буде дозволено, нагадуючи про використання засобів, щоб не перевантажувати прооперовану кінцівку. Рання рухливість запобігає розвитку ускладнень: пневмонії та тромбоемболії, однак варто застосовувати відповідні методики для запобігання травмуванню прооперованої кінцівки;

- проведенні фізіотерапії і виконанні відповідних вправ для чотириголового м'яза стегна (піднімання ніг, пасивних та активних рухів), які допомагають запобігти атрофії м'язів і тромбоемболії, зміцнюючи м'язи ураженої кінцівки так, щоб вона могла підтримувати протез суглоба. Пацієнту з тотальною заміною кульшового суглоба не рекомендоване згинання стегна більше ніж 90 градусів або значне приведення ураже- ної ноги для попередження вивиху суглоба. Крім того, запобігти тромбоемболії та емболії легеневої артерії у пацієнта, який повинен залишатися нерухомим після операції, дозволяє застосування компресійних (антиемболічних) панчохів.

У пізній післяопераційний період (від 5-7 до 17-21 дня після операції) основними завданнями $\epsilon$ поліпшення трофіки тканин оперованого суглоба, зміцнення м'язів нижніх кінцівок і плечового пояса, зміцнення м'язів спини та сідничних м'язів, підготовка хворого до самостійного обслуговування в домашніх умовах, поліпшення діяльності серцево-судинної та дихальної систем, активізація периферійного кровообігу, навчання хворого ходьбі з милицями. Медична сестра заохочує до споживання збалансованого раціону з достатнім вмістом білків, необхідних у процесі загоєння тканин, вживання достатньої кількості рідини і дієти з високим вмістом клітковини, оскільки ліжковий режим спричиняє розвиток закрепів. За необхідності застосовують пом'якшувальні ректальні свічки.

На цьому етапі медична сестра навчає як виконувати вправи після виписування зі стаціонару, ознайомлює з особливостями обмеження активності. Підкреслює важливість планових відвідувань лікарів.

Висновки. Враховуючи виявлені під час діагностичного пошуку порушення, медична сестра може визначити потенційні проблеми пацієнтів, які потребують операційного лікування коксартрозу та які перенесли операцію ендопротезування. Керуючись знаннями, їй легше сформувати план догляду за такими пацієнтами на етапі їх стаціонарного лікування. Дотримання описаних медичних технологій сприяє вирішенню питання швидкого відновлення працездатності хворих після ендопротезування та покращення якості їх життя.

4. Петрущак О. М. Роль медичної сестри на сучасному етапі розвитку охорони здоров'я / О. М. Петрущак, І. Я. Криницька // Медсестринство. - 2017. - № 4. - С. 48-50. 5. Попова Л. А. Коксартроз в структуре заболеваний опорно-двигательной системы: современный взгляд на этиологию, патогенез и методы лечения / Л. А. Попова, Н. В. Сазонова, Е. А. Волокитина // Гений ортопедии. 2006. - № 4. - С. 91-98.

6. Януш Я. Л. Участь медичної сестри в програмі реабілітації після ендопротезування кульшового суглоба в хворих похилого та старечого віку / Я. Л. Януш // Медсестринство. - 2012. - № 4. - С. 29-32. 
7. Quality and safety education for nurses / L. Cronenwett, G. Sherwood, J. Barnsteiner [et al.] // Nursing Outlook. 2007. - No. 55. - P. 122-131.

8. Herbold J. A. Rehabilitation following total knee replacement, total hip replacement, and hip fracture: a case-controlled comparison / J. A. Herbold, K. Bonistall, M. B. Walsh // J. Geriatr. Phys. Ther. - 2011. - No. 34 (4). P. 155-160.

9. Lee M. Nursing care patterns for patients receiving total hip replacements / M. Lee, S. Moorhead // Orthop Nurs. 2014. - No. 33 (3). - P. 149-158.
10. Lucas B. Total hip and total knee replacement: postoperative nursing management / B. Lucas // Br. J. Nurs. 2009. - No. 17 (22). - P. 1410-1414.

11. Predictive factors influencing fast track rehabilitation following primary total hip and knee arthroplasty / M. Schneider, I. Kawahara, G. Ballantyne [et al.] // Arch. Orthop. Trauma Surg. - 2009. - No. 129 (12). - P. 1585-1591.

Отримано 29.01.19 